\title{
Pneumologia
}

\section{Pulmonary rehabilitation following the 2019 novel Coronavirus infection}

\author{
Safae El Haddaoui ${ }^{1,2, *}$, Youssra Amekran ${ }^{1}$, Abdelkader Jalil El Hangouche ${ }^{1,3,4}$
}

${ }^{1}$ Department of Physiology, Faculty of Medicine and Pharmacy of Tangier, Abdelmalek Essaadi University, Tangier, Morocco ${ }^{2}$ Department of Physiotherapy, Mohammed VI Hospital of M'diq, Morocco

${ }^{3}$ Department of Cardiology, University Hospital Tangier - Tetouan - Al Hoceima, Tangier, Morocco

${ }^{4}$ Department of Physiology, Exercise Physiology and Autonomic Nervous System Team "EPE-SNA", Faculty of Medicine and Pharmacy of Rabat, Mohamed V University, Rabat, Morocco

Abstract

English:

The treatment of an infectious disease is only one step to a cure and, in many cases, infectious diseases can lead to shortand long-term impairments, including physical, cognitive and psycho-emotional complications. In this paper, we perform a literature review to identify the appropriate rehabilitation interventions for responding to COVID-19 consequences, taking into consideration the current standards for pulmonary rehabilitation and the COVID-19 literature which has been developed during the pandemic's evolution. Pulmonary, neurological, cardiac, musculoskeletal, nutritional, cognitive and psychological disabilities, as well as dysphasia, have been observed among patients who recovered after needing time in the intensive care unit (ICU), related either directly to COVID-19 or critical care treatments. Some have also been reported in patients who were asymptomatic or recovered from a mild or moderate form of the disease. Patients who still have dyspnea, exercise intolerance and fatigue, are unable to conduct activities of daily living and/or have difficulty in managing or coping with their disease, despite optimised pharmacological therapy, are most likely to benefit from pulmonary rehabilitation. Contraindications should be considered during patient selection. Rehabilitation prescription should be individually tailored, based on patient assessment and outcome measurements. Pulmonary rehabilitation interventions may involve airway clearance therapy, breathing exercises, mobilisation and strength training, flexibility training, balance training, neuromuscular electrical stimulation (NMES), activities of daily living, aerobic training, dysphagia management, nutrition therapy, cognitive training and psychological support. Medical management of comorbidities and patient-family education are key factors for achieving optimal gains from pulmonary rehabilitation.

Keywords

\section{Reabilitare pulmonară în urma infecției cu noul coronavirus 2019}

Rezumat

\begin{abstract}
Romanian:
Tratamentul unei boli infectioase este la un pas departare de vindecare și, în multe cazuri, bolile infectioase pot duce la afectări pe termen scurt și lung, inclusiv complicații fizice, cognitive și psiho-emoționale. În această lucrare, efectuăm o revizuire a literaturii pentru a identifica intervențiile adecvate de reabilitare care sa abordeze consecintele COVID-19, luând în considerare standardele actuale pentru reabilitarea pulmonară și literatura COVID-19 care a fost dezvoltată pe parcursul evoluției pandemiei. Au fost observate dizabilități pulmonare, neurologice, cardiace, musculo-scheletice, nutriționale, cognitive și psihologice, precum și disfazie, în rândul pacienților care și-au revenit după ce au stationat în unitatea de terapie intensivă, legate fie direct de COVID-19, fie de tratamentele de îngrijire critică. Unele au fost raportate și la pacienții asimptomatici sau recuperați de la o formă ușoară sau moderată a bolii. Pacientii care încă au dispnee, intolerantă la efort și oboseală, sunt incapabili să desfăsoare activităti din viața de zi cu zi și / sau au dificultăți în gestionarea bolii lor, în ciuda terapiei farmacologice optimizate, sunt cei care vor beneficia cel mai probabil de reabilitarea pulmonară. Contraindicațile trebuie luate în considerare în timpul selectiei pacientului. Programul de reabilitare trebuie adaptat individual, pe baza evaluării pacienților și a măsurătorilor rezultatului. Intervențiile de reabilitare pulmonară pot implica terapie de drenaj a căilor respiratorii, exerciții de respirație, mobilizare și antrenament de forță, antrenament de flexibilitate, antrenament de echilibru, stimulare electrică neuromusculară, activități de viață de zi cu zi, antrenament aerobic, management al disfagiei, terapie nutrițională, antrenament cognitiv și sprijin psihologic. Managementul medical al comorbidităților și educația pacient-familie sunt factori cheie pentru obținerea câștigurilor optime din reabilitarea pulmonară.
\end{abstract}

Cuvinte-cheie

SARS-CoV-2 • COVID-19 • Reabilitarea Pulmonară • Evaluare

${ }^{*}$ Corresponding author: Safae El Haddaoui

E-mail: safelhaddaoui@gmail.com

ว Open Access. @ 2021 El Haddaoui et al., published by Sciendo

(c) Br-Nc-ND This work is licensed under the Creative Commons Attribution-NonCommercial-NoDerivs 4.0 License. 


\section{Introduction}

In late December 2019, a novel Coronavirus was identified after the Chinese health system in Wuhan declared a continuously increasing number of patients with common viral pneumonia $(1,2)$. Shortly afterwards, the World Health Organization (WHO) recognised the new coronavirus disease as COVID-19 (3). On 11 March 2020, COVID-19 became a pandemic and caused a major global public health issue $(4,5)$. At the time of writing this paper, more than 29 million positive cases have been registered and over $9,00,000$ deaths have been reported according to the WHO (6).

The angiotensin-converting enzyme 2 (ACE2) was found to be a key host receptor for SARS-CoV-2 (2). Organ cells that have a significant ACE2 expression level are the main targeted cells, including the lung alveolar epithelial cells, enterocytes of the small intestine, heart and kidney, which explain the respiratory and non-respiratory clinical features in patients $(7,8)$. The human-to-human transmission occurs essentially by means of the respiratory tract via droplets from sneezing, coughing or rhinorrhoea within $2 \mathrm{~m}$ of the infected person $(2,9)$.

Several forms of COVID-19 have been characterised based on symptoms and the degree of severity. The first form refers to asymptomatic patients. The second form refers that the patients may present as symptomatic with mild or moderate symptoms which commonly include fatigue, fever, dry cough, headache, sore throat, nasal congestion, myalgia and arthralgia (10), though some patients have experienced particular symptoms such as keratoconjunctivitis (11), anosmia and ageusia (12). The third form includes severeto-critical cases, usually associated with people of advanced age or patients with comorbidities such as diabetes, hypertension, cardiac and cerebrovascular diseases (10), as well as hepatic and renal dysfunction (13). In this form, a cytokine storm eventually occurs and results in a prolonged and excessive inflammatory response to SARS-CoV-2, causing multiple-organ dysfunction or acute respiratory distress syndrome (ARDS) which can lead to physiological deterioration and death (14).

To date, there is no specific treatment for COVID-19. Optimised supportive care remains the current mainstay of treatment (15). However, some antiviral agents such as hydroxychloroquine, chloroquine, remdesivir, favipiravir and lopinavir/ritonavir are being used (15). Corticosteroid and anticoagulant agents have also been utilised when the need was justified (10).

Cases evolving into acute pneumonia, ARDS, severe cardiovascular complications, acute kidney injury, sepsis and septic shock are indications for intensive care unit (ICU) admission $(10,16,17)$. At this stage, the management guidelines for these patients encompasses using lungprotective ventilation, neuromuscular blocking agents to optimise ventilator synchrony, conservative fluid strategies, empirical antibiotics for a potential bacterial superinfection with aggressive de-escalation, prone positioning as appropriate, and extracorporeal membrane oxygenation is considered in the cases of refractory hypoxemia (16).

Based on the past experiences in patients with SARS (18), functional, radiological and psychological impairments of different degrees have been reported in recovered patients, mainly characterised by dyspnea and general weakness, including physical limitations and reduced aerobic capacity over 1 month following hospital discharge. Computerised tomography (CT) of the chest showed some patchy changes indicating pulmonary fibrosis. These patients also manifested symptoms of psychological trauma about 1 month from the onset of illness. Furthermore, in the cases of severe SARS (19), survivors continued to experience long-term effects of physical dysfunction 1 year after survival; this included an impact on their occupational and social participation, in addition to the manifestation of high degrees of stress, anxiety and depression. Given these results, Landry et al. (20) concluded that the infectious disease treatment is only one step and that, in many cases, infectious diseases may result in lasting impairments, mainly activity limitations and participation restrictions. Moreover, several reports $(21,22)$ stated that the median length of COVID-19 patients' stay in ICU is $2-3$ weeks, which is relatively long $(22,23)$. Stam et al. (24) indicated that the risk for physical, cognition and psychoemotional complications, respectively, increases with the patient's length of stay (LOS) in the ICU. Additionally, there is growing evidence in the literature that patients recovering from COVID-19 can experience short- and long-term consequences resulting from either the disease itself or ICU hospitalisation $(22,23,24)$. On the other hand, rehabilitation has shown promising results in reducing disability and improving clinical outcomes in survivors during disasters (25). Consequently, incorporation of rehabilitation following COVID-19 is essential. Therefore, we have performed this literature review, to identify the appropriate rehabilitation interventions to effectively respond to a wide spectrum of COVID-19 issues, taking into consideration the pulmonary rehabilitation (PR) standards and the COVID-19 literature developed along with the pandemic evolution.

\section{COVID-19 consequences}

In addition to asymptomatic patients, COVID-19 has a different clinical spectrum. In a report by Carda et al. (23), COVID-19 degrees of severity are divided into four forms: (1) Mild: normal blood oxygen saturation $\left(\mathrm{SatO}_{2}\right)$ and no dyspnea; (2) Moderate: SatO 2 94-98\%, dyspnea and radiological signs of pneumonia; (3) Severe: respiratory rate $(R R)>30 / m i n$, 
$\mathrm{SatO}_{2} \leq 93 \%$, radiological progression of lesions, dyspnea and oxygen therapy with non-invasive ventilation might be needed and (4) Critical: patients require mechanical ventilation. Furthermore, the consequences of COVID-19 resulting from each form can range from a transitory impact to a long-lasting impact. Addressing these consequences by PR based on a multidisciplinary rehabilitation team finds indication evidence in the literature.

\section{In asymptomatic COVID-19}

Patients usually recover without any CT findings, nor any residual dysfunctions $(23,26)$. However, based on the results of a retrospective study (27) on the radiological findings from 81 patients with COVID-19 in Wuhan, 15 asymptomatic patients were found with evolving lung lesions which persisted until after a short period of treatment. CT imaging showed a rapid progression, within 1-3 weeks, from focal unilateral to diffuse bilateral ground-glass opacities (GGO) that coexisted with or developed into consolidations. These findings indicate interstitial changes and suggest substantial fibrotic consequences following COVID-19 infection. These patients may also develop psychological problems such as anxiety and depression due to experiencing loneliness, insomnia and fear during quarantine (28).

\section{In mild-to-moderate COVID-19}

CT imaging revealed various lung lesions, mostly characterised by GGO that could evolve into consolidation and fibrosis (26). These findings were presented more in male and older patients (26). Following the SARS-CoV-2 infection, a randomised controlled study (29) demonstrated that a 6-week respiratory rehabilitation period was deemed to be effective in improving the prognosis for respiratory function, mobility, psychological function and quality of life (QoL).

\section{In severe and critical COVID-19}

An acute systemic inflammatory response to SARS-CoV-2 can result in acute pneumonia, ARDS (17), severe cardiac complications (16), sepsis and septic shock (17), which can also lead to death (30). These patients are admitted to the ICU for supportive therapy (31). They are usually older patients ( $>60$ years) with impaired immunity and/or a medical history of comorbidity, including diabetes, hypertension, coronary artery disease, ischemic disease of the central nervous system, Parkinson's disease and bronchitis (17). After 2-3 weeks, ICU survivors may be discharged with multiple impairments, varying between respiratory dysfunction, extrapulmonary disorders and post-intensive care syndrome (PICS), resulting in either from COVID-19 complications or the consequences of ICU treatment $(22,23,24)$.

\section{Respiratory impairments}

Due to diffuse lung injury occurring in severe COVID-19 patients (30), some patients present with persistent dyspnea after the acute phase. This is usually associated with low SatO $_{2}$, which may manifest at rest and/or on exertion (23). Spirometry and pulmonary diffusion capacity tests in discharged severe COVID-19 patients showed an impaired diffusion capacity, followed by restrictive ventilatory defects (32). In critical COVID-19 patients, as described in the preexisting literature, ARDS survivors may also have abnormal lung function and reduced exercise endurance, which, despite being generally minor, may persist for up to several years after the acute illness (33). Herridge et al (34) conducted a prospective cohort study of 109 ARDS survivors to evaluate lung function and exercise capacity 1 year after surviving intensive care. They found that patients had mild restrictive disease and decreased diffusion capacity up to 3 months after discharge. Spirometric measurements and lung volume were almost normal, though with a persistent minor reduction in diffusion capacity associated with dyspnea and sputum production at 6 months and 12 months. At 12 months, the distance walked in 6 min was significantly increased but remained below the predicted value. Exercise limitation was attributed to global muscle wasting (patients lost $18 \%$ of their baseline body weight) and weakness. Persistent dyspnea at 12 months after the onset of the illness was most likely the result of diaphragmatic dysfunction rather than a specific lung problem (35). These findings suggest the role of a global assessment in order to determine the functional limitations contributing to health-related quality of life (HRQL) decrements in ARDS survivors, and consequently in those surviving COVID-19. PR, likely associated with oxygen therapy, would be also crucial in patients who have been through severe and critical stages of COVID-19 $(22,36)$.

\section{Post-extubation dysphagia (PED)}

Although the prevalence of PED in COVID-19 patients was not reported, the significant prevalence of critical COVID-19 patients requiring invasive mechanical ventilation (according to the New England Journal of Medicine study (37), almost $60 \%$ of ICU patients needed mechanical ventilation) suggests the presence of PED in a large number of patients after extubation. PED can delay the return to normal oral feeding and increase the risk of morbidity and mortality related to aspiration pneumonia. Speech-language pathology (SLP) or physiotherapy intervention can be very effective in reducing these effects $(38,39)$. 


\section{Cardiac impairments}

The association between COVID-19 and cardiovascular disease is continually outlined. Cardiac arrhythmias and myocardial ischemia are the most reported cardiac events in patients with severe COVID-19 (16). Various aetiologies have been explored, including unstable pre-existing chronic cardiac diseases, respiratory dysfunction and hypoxemia, viral myocardial injury, ACE2-receptor down-regulation, accentuated inflammatory response and corticosteroids use in COVID-19 patients with cardiac context (40). The Stanford Hall consensus recommends that patients recovering from COVID-19 with new or worsening cardiovascular events should undergo a comprehensive cardiac assessment, followed by a period of rest before integrating any rehabilitation programme to reduce the risk of post-infection cardiac failure secondary to myocarditis (41).

\section{Neurological impairments}

Several cases with severe COVID-19 have been identified with variable neurological disorders. The potential 'Neuroinvasion' of SARS-CoV-2 appears to be the result of a haematogenous spread through the central and peripheral nerve pathways (39). The neurological signs of the central nervous system involvement include consciousness alterations, acute cerebrovascular disease, dizziness, headache, seizure and ataxia (42). Peripheral impairments include peripheral axonal neuropathy, Guillain-Barrè syndrome (43) and sensory disability comprising of a loss of taste, smell and vision (23). Mild neurological disorders showed to be transient, while the severe ones seem to persist longer and cause difficulties with daily tasks $(41,44)$.

\section{Post intensive care syndrome (PICS)}

This is related to ICU-acquired weakness (ICU-AW), cognitive and mental impairments manifested during ICU stay, and following ICU/hospital discharge, including the long-term prognosis of ICU survivors (45). Severe COVID-19 patients who undergo ICU treatment are at increased risk of developing short- and long-term problems associated with PICS $(22,46)$.

1) ICU-AW: All four limbs and respiratory muscles are affected by weakness, the diaphragm is often involved (47). ICU-AW is likely to be multifactorial and may result from prolonged proning, duration of mechanical ventilation, treatment modalities, systemic inflammatory response syndrome, multiorgan failure and sepsis $(22,45)$. An early report (21) stated that $30 \%$ of severe COVID-19 patients were diagnosed with ICU-AW at ICU discharge. Similarly, the early experience from the field (22) reported that many functional issues were diagnosed in COVID-19 patients following ICU discharge. For example, severe muscle weakness, fatigue, neck and shoulder pain, joint stiffness, difficulty in verticalisation, impaired balance and gait, reduced mobility, limitations in activities of daily living and work were indicated. Persistent respiratory muscle weakness and limb weakness at ICU discharge predict poor clinical outcomes and an increased risk of death or readmission to hospital or ICU (48).

2) Cognitive impairments: These include dementia, impaired attention, language deficits, diminished executive function and reduced visual-spatial abilities (45). Patients with delirium in the ICU are at significant risk for long-term consequences of cognitive dysfunction (45). Potential aetiology is direct CNS viral involvement and/or hypoxemia (49). A systematic review (50) on psychiatric and neuropsychiatric presentations associated with severe Coronavirus infections found that $65 \%$ of ICU patients with severe COVID-19 developed delirium (confusion) and $21 \%$ of patients who subsequently died had altered consciousness. At discharge, 33\% had dysexecutive syndrome with symptoms such as disorientation, inattention or poorly organised responding movements to commands. Similar findings were reported in a different study (21), where mild to moderate delirium was present in all COVID-19 patients who were discharged from ICU.

3) Mental impairments: This issue might result from direct effects of a viral brain infection, the context of a procoagulant state, hypoxia, an immunological response, medical intervention and environmental factors like social isolation and/or stigma $(50,45)$. A report (21), including a small cohort with severe and critical COVID-19, found that anxiety or post-traumatic stress was present in $50 \%$ of patients after being discharged from ICU. The long-term mental health effects of COVID-19 are yet to be examined. However, the past epidemics with the SARS and MERS infections provide early insights into the mental outcomes of COVID-19. A meta-analysis (50) including 1,203 patients on a post severe illness stage of SARS and MERS revealed that $32.2 \%$ of cases developed post-traumatic stress disorder (PTSD), $14.9 \%$ had depression and $14.8 \%$ suffered from anxiety disorders. Additionally, the study suggests that if COVID-19 has the same infection course as SARS and MERS, possible long-term neuropsychiatric consequences should be expected in severe COVID-19 survivors.

The prevention of PICS from time in ICU is showed to be more effective than the intensive treatment of PICS upon ICU discharge (51). Early rehabilitation during ICU time may reduce ICU-AW (52) but has not shown significant improvement on PICS-related delirium and mental issues (53). Cuthbertson et 
al. (54) studied the effects of an ICU follow-up programme on the HRQL of 192 ARDS survivors and the results indicated no improvement on Short Form-36 (SF-36) physical or mental component scores at 12 months post-discharge. Additionally, the programme was considerably expensive compared with the standard care. However, a series of studies have reported positive results of PR outcomes in ARDS survivors. In a case report (55), 1 month of respiratory rehabilitation followed by daily regular physical activity showed regression of alveolar condensation at about 1 month, increased activity tolerance at 3 months and alleviation of dyspnea at 6 months. In another study, Hsieh et al. (56) assessed recovery of pulmonary functions, exercise capacity and QoL upon a 2-month PR programme following ARDS caused by severe influenza A (H1N1) pneumonitis. The results revealed improvement in pulmonary functions and exercise capacity, as well as continuous progress in the total lung capacity and QoL, respectively, 1-3 months and 6 months after ICU discharge. The effect of a multicomponent rehabilitation programme on the cognitive functions following ICU discharge was investigated by Jackson et al. (57). The 3-month rehabilitation programme based on the cognitive, physical and functional training demonstrated a significant improvement in the cognitive executive functioning in ICU survivors. On the other hand, although the lack of studies evaluating the effectiveness of PR on psychiatric disorders in ICU survivors, a systematic review and meta-analysis (58) comprising 11 studies reported the PR's significant benefits on anxiety and depression symptoms in patients with chronic obstructive pulmonary disease (COPD). Furthermore, Panagioti et al. (59) concluded that PR interventions either with or without psychological component ameliorate symptoms of anxiety and depression in COPD. Subsequently, PR can confer beneficial effects in COVID-19 survivors, as well as in those at risk of PICS after ICU discharge.

\section{PR following the acute stages of COVID-19}

\section{Referral to PR}

Based on multiple outcomes resulting from COVID-19 infection, a comprehensive multidisciplinary team intervention comprising of the physician, physiotherapist, nurse, dietician, social worker, occupational therapist, pharmacist and speech therapist, alongside the psychologist will be necessary $(39,41$, 60 ). The patient's awareness of his disability and full motivation for improvement is a valuable contribution to the treatment effectiveness and their recovery (60). Patients who have recovered from COVID-19 infection, but still have dyspnea, exercise intolerance and fatigue are unable to conduct activities of daily living and have difficulty in managing or coping with their disease, despite optimised pharmacological therapy, are most likely to benefit from PR $(41,61)$. PR is feasible within all rehabilitation settings. This involves hospital inpatient, hospital outpatient, the community and the home. Patients with pulmonary sequelae such as breathlessness, bronchiectasis or pulmonary fibrosis can safely benefit from tailored PR programmes (60). Patients with significant cardiac disease, locomotor problems or severe cognitive impairments will be limited in their ability to exercise or comprehend $(60,41)$. COVID-19 patients with mild-to-moderate outcomes may be therefore able to undergo outpatient or homebased rehabilitation, while older adults with comorbidities and severe COVID-19 survivors who have been discharged from the ICU are at risk of deteriorating and should first be stabilised before undergoing a long rehabilitation process within the inpatient, outpatient and home settings $(28,36)$. Rehabilitation prescription has to be individually tailored, based on the patient assessment and outcome measurements (61). The PR programme can be adjusted to meet certain patient dysfunctions and their preexisting or new comorbidities $(60,22,46,61)$.

\section{Patient assessment, outcome measurements and monitoring}

The referral of COVID-19 patients to PR should consider the main contraindications to PR described in Figure $1(61,62)$. The patient must show evidence of COVID-19-free status with documentation of two consecutive negative real-time reverse transcription polymerase chain reaction (RT-PCR) results at 24-h intervals (62). To ensure the patient's eligibility and safety to be enrolled in a PR programme, PR program staff should review the patient's formal medical assessment, including their medical history, physical examination, chest imaging, review of laboratory tests such as complete blood count, chemistries, electrocardiogram (ECG) and pulmonary function testing, as well as blood gas, oximetry testing and ECG stress testing if available. Patient comorbidities should be assessed before and monitored during PR (61). It is important to consider cardiopulmonary exercise testing for exercise intolerance assessment and/or 6-min walk test (6MWT) at the start of PR to formulate the exercise prescription $(28,63)$. Outcome measurements should be considered to assess and monitor the patient's progress, exercise safety and the PR programme's effectiveness (61). Figure $2(28,64,65)$ summarises the common
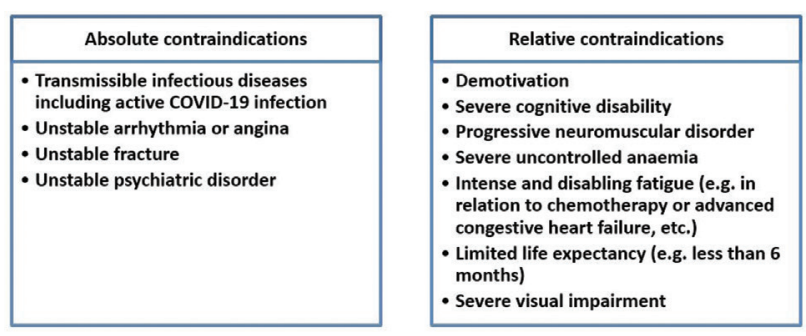

Figure 1. Contraindications to pulmonary rehabilitation. 


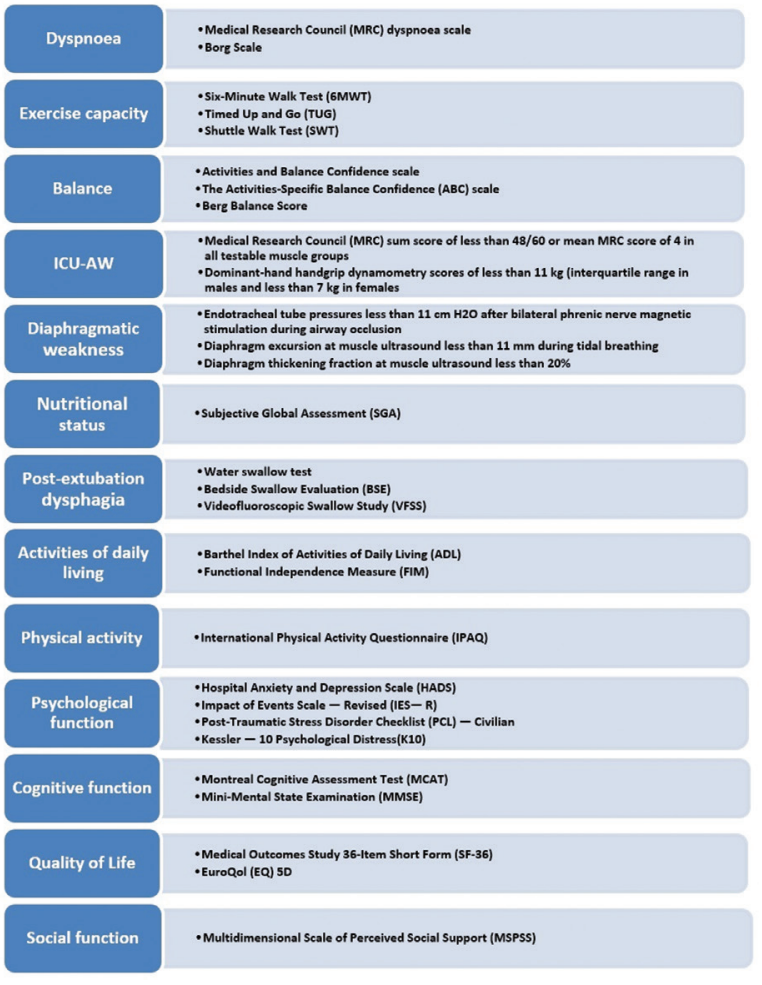

Figure 2. Common instruments for outcome measurements potentially used after COVID-19. ADL, Barthel index of activities of daily living; BSE, bedside swallow evaluation; EQ, EuroQol; FIM, functional independence measure; HADS, hospital anxiety and depression scale; IES-R, impact of events scale-revised; ICU-AW, ICU-acquired weakness; IPAQ, International physical activity questionnaire; K10, Kessler-10 psychological distress; MRC, Medical Research Council; MCAT, Montreal cognitive assessment test; MMSE, mini-mental state examination; MSPSS, multidimensional scale of perceived social support; PCL, post-traumatic stress disorder checklist; 6MWT, Six-minute walk test; SWT, shuttle walk test; SGA, subjective global assessment; SF-36, medical outcomesstudy36-item short form; TUG, timed up and go; VFSS, videofluoroscopic swallow study.

instruments for measuring COVID-19-related outcomes. When there are multiple outcomes to be evaluated, the assessment could be an exhausting process, especially for critical care survivors at the early stage of recovery. Therefore, it may be judicious to select the outcomes of most interest for the treatment guidance. Exercise capacity, dyspnea and QOL are usually key areas for demonstrating the benefits of PR for patients (61). During exercise sessions, the patient should be monitored. The session should be discontinued if the following signs are identified: blood pressure $<90 / 60$ or $>140 / 90$, decreased $\mathrm{SaO}_{2}(<95 \%)$, heart rate $>100$, temperature $>37.2$, chest pain, dizziness, loss of balance, heart palpitations, excessive fatigue, severe cough, blurred vision, headache or profuse sweating $(66,28)$.

\section{Management of comorbidities}

Severe COVID-19 is recognised to be associated with comorbidities such as cardiovascular diseases (heart failure, coronary artery disease or cardiomyopathies), metabolic diseases (diabetes, hypertension, obesity) and COPD (67). Poor PR outcomes can relate to the presence of comorbidities. Maintaining these comorbidities in balance before beginning PR may increase the patient's chances of achieving the optimal gains from PR $(68,61)$.

\section{PR interventions}

\section{Airway clearance therapy}

Sputum rarely occurs in patients who experienced a mild or moderate form of COVID-19 infection. However, in severe COVID-19 cases that required ICU treatment, bronchial secretions should be controlled (22). An augmented amount of sputum may result from lung abnormalities and complications such as bronchiectasis, secondary bacterial infection and aspiration pneumonia (69). Expectoration deficiency is usually associated with an ineffective cough, indicating a reduction in expiratory flow and respiratory muscle weakness (70). Accumulated bronchial secretions can worsen dyspnea, potentiating the risk of atelectasis, reductions in lung compliance and secondary infections (71). Respiratory secretion management will aim to increase mucociliary clearance, moving the secretions to the upper airways, promoting expectoration and improving cough effectiveness (70). The choice of techniques or devices to promote expectoration and improve mucus clearance should consider the initial and ongoing pulmonary function assessment, the patient's cognitive ability, comorbidities and respiratory muscle strength (72). Cough effectiveness can be improved by activating the expiratory muscles, achieved by either an external stimulus (e.g. functional electrical stimulation) or expiratory muscle training (70).

\section{Breathing exercises}

Inspiratory muscles and diaphragmatic weakness are mainly reported in COVID-19 patients who required a considerable duration of mechanical ventilation and subsequently lose spontaneous breathing ability (28). After a successful spontaneous breathing trial, applying well-controlled breathing exercises may relieve dyspnea, improve the respiratory muscle function, ventilation and gas exchange, exercise tolerance and QoL. These exercises comprise body positions such as leaning forward, relaxation therapy and inspiratory and expiratory muscle training (66). Exercise should include non-threshold load training for inspiratory muscles, with intensity starting from $30 \%$ of the maximal inspiratory pressure, for a duration of 10-15 $\mathrm{min} /$ day, with 
a goal of gradually increasing to $30 \mathrm{~min} /$ day (36). During diaphragmatic breathing, the patient is taught to intentionally move the abdominal wall during inspiration while reducing the upper ribcage motion. Then they exhale deeply and slowly against pursed lips while contracting the abdominal muscles. The exercise should be performed for $10 \mathrm{~min}$, three times per day. It includes four respiratory progression positions: supine, proning, sitting and walking $(36,73)$.

\section{Mobilisation and strength training}

Ideally, mobilisation is most effective when addressed early during ICU. However, COVID-19 patients who present with unsatisfactory mobility after ICU discharge would also benefit from mobility exercises to achieve recovery (46). Mobilisation may improve short- and long-term functional status, cognitive faculties (but not delirium) and respiratory conditions. It could also prevent thromboembolism risk and reduce hospital LOS $(74,45)$. It comprises passive, active-assisted, active mobilisation (against resistance) of upper and lower limbs, and activities such as sitting, standing and ambulation $(45,62)$. Resistance training should be individualised and progressive. The chosen resistance for each muscle group should be at $70-80 \%$ of the person's one-repetition maximum (46), with at least $48 \mathrm{~h}$ of recovery between sessions of the same muscle group, during 4-6 weeks $(63,75)$. A recommended programme suggests 8-12 repetitions maximum for the training load of each muscle group, for 1-3 sets, with a 2-min recovery period between sets, for $2-3$ sessions/week, lasting for 6 weeks, with $5-10 \%$ of training load progression per week (28).

\section{Flexibility training}

Due to prolonged immobility, muscle weakness and joints stiffness can lead to an abnormal body posture. As a result, reduced pulmonary function, shallow respiration, altered body mechanics and back pain are potential problems in COVID-19 survivors (23). Flexibility exercises may significantly improve the vital capacity, exercise tolerance and pain level. Training includes stretching exercises of the main upper and lower limb muscle groups, as well as the shoulders, trunk and neck motion exercises and thoracic expansion. Training can last for 5 min, once a day, for at least 2-3 days/week $(36,63)$.

\section{Balance training}

The balance should be based on an assessment to identify the area of dysfunction. Exercises have to be individually tailored and developed according to the patient's ability (51). Training may include static, dynamic, hands-free balance and using balance training instruments $(28,36,46)$. Patients should be supervised by the rehabilitation therapist who must be careful to avoid the potential of risky patient falls, especially in those who are on anticoagulants treatment (63).

\section{Neuromuscular electrical stimulation (NMES)}

This has the advantage of improving muscle contraction strength without involving the cognitive, psychological and motivational aspects, otherwise required in conventional muscle training (63). In just 4 weeks of treatment, NMES has been shown to be effective in treating severely disabled patients with COPD and a poor baseline exercise tolerance. Improvement comprised of an increase in limb muscle strength, exercise capacity and dyspnea (63). These improvements would also be beneficial for COVID-19 survivors with acute deconditioning. NMES stimulus frequencies up to $10 \mathrm{~Hz}$ and $30 \mathrm{~Hz}$ are optimal for activating slow-twitch fibres (endurance function) and fast-twitch muscle fibres (power function), respectively (63). It is generally safe and well-tolerated and can be applied in inpatient, outpatient and home settings. However, there are several contraindications for use regarding patients with implanted pacemakers or defibrillators, patients with uncontrolled cardiac arrhythmias, recent myocardial infarction, unstable angina, intracranial clips and/or total knee or hip replacement (63).

\section{Activities of daily life}

Occupational therapy support is important in disabled COVID-19 patients, since it likely contributes to faster recovery, improved patient functional independence and reduced hospital LOS. The interventions should be targeted based on the assessment of patient's ability to perform or adapt to their ADLs $(39,66)$.

\section{Aerobic (endurance) training}

These include walking, bicycle training, slow jogging, swimming, ergometer and so on. At the beginning of training, intensity should be low to less than three metabolic equivalents of task, for a session of 20-30 min, which can be repeated 3-5 times/week, before gradually increasing in intensity and duration $(28,66)$. Aerobic exercises should be individually tailored and take into consideration the patient's comorbidities (28). Hornikx et al. (68) concluded that endurance exercise should be reformed so as to be adapted to the patient's underlying chronic disease and that this category of patients could get the most benefit of rehabilitation. Figure 3 (68) summarises the outpatient endurance training intensity based on the patient-specific comorbidity.

\section{PED management}

Compensatory manoeuvres aim to reduce the risk of aspiration and improve chewing and swallowing. They consist of modifying dietary textures (preferably thick liquids and chopped solid food), the patient attempting to swallow small amounts, swallowing several times, coughing each time after swallowing, or using the Mendelsohn manoeuvre 


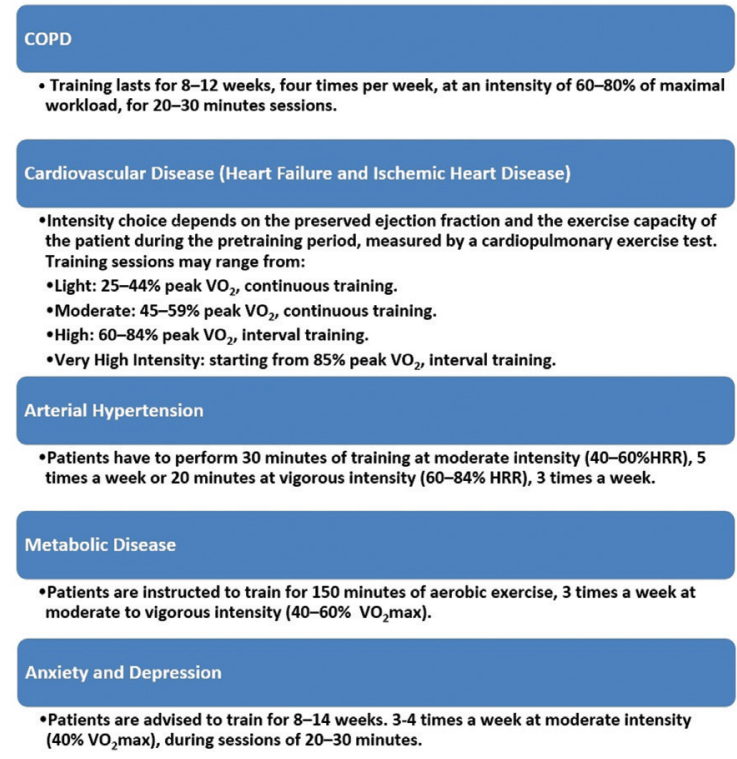

Figure 3. Outpatient endurance training intensity regarding the patient comorbidity. COPD, chronic obstructive pulmonary disease; CVD, cardiovascular disease; HF, heart failure; IHD, ischemic heart disease.

(voluntary prolongation of hyolaryngeal elevation at the peak of the swallow). During rehabilitative techniques, the speechlanguage pathologist educates the patient in adopting new postures such as turning the head to one side or placing the chin down while swallowing. They also initiate therapeutic exercises comprising of progressive strengthening and coordination of swallowing muscles, which are also involved in voice recovery $(38,76)$.

\section{Nutrition therapy}

Nutritional status is an important factor in recovery from critical illness. Upon discharge from the ICU, patients usually present with a condition of malnutrition associated with poorer functional outcomes including severe skeletal muscle loss (45). Therefore, severe COVID-19 survivors should be screened for malnutrition risk. Several studies $(64,77,78)$ have reported that nutrition therapy based on protein delivery, combined with appropriate rehabilitation, can maximise muscle protein synthesis and reduce ICU-AW.

\section{Cognitive training}

Severe COVID-19 survivors are most likely to develop cognitive problems after a long LOS in ICU. The treatment of ICU-acquired delirium is challenging, generally based on a range of preventive measures that must be considered at the earliest stage of ICU treatment (62). These measures aim at using - when possible - short-acting sedatives, light sedation protocols, patient's reorientation, sleep hygiene, hypoxemia management, minimising pathologic changes in blood pressure, daily spontaneous awakening trials and spontaneous breathing trials, early mobilisation, and family engagement and empowerment (79). A cognitive rehabilitation approach comprises of techniques to remediate the loss of attention, memory (visual imagery exercise, notebooks or computerised activities), problem-solving ability (learn to monitor, manage and regulate the orderly 'execution' of goal-directed ADLs), as well as comprehension (paraphrasing exercises, repeating messages back to the therapist or using adapted handouts to ensure the patient's understanding) $(46,80)$.

\section{Psychological support}

An aspect of great value in the management of all COVID-19 patients, it should be considered at all stages of the course of disease and recovery. Physicians and nursing staff should try to build an empathic, compassionate therapeutic alliance with the patient and family, either during the isolation period or the acute phase of the disease (45). Regular video conferencing or telephone communication is required to establish and maintain the connection between the patient and their family, as well as between healthcare providers and the family (22). Early rehabilitation during ICU in patients with critical illness did not show a significant improvement in the long-term mental outcomes, whereas ICU diaries were written or recorded by a patient or a medical person may have prevented PICS by alleviating anxiety, depression, and post-traumatic stress disorder (PTSD) symptoms (45). After hospital discharge, intentional follow-up of the patient's health status via telephone would provide a needed emotional security for the patient who may feel abandoned or distressed (22). Counselling sessions may also be considered (39).

\section{Patient-family education}

- Recovering from COVID-19 is an opportunity to offer smoking cessation advice for active smokers (62).

- Patients with remained impaired bronchopulmonary secretion clearance should be taught techniques favouring secretion removal (39).

- Dietary advice should be addressed to patients who are obese or have a low body mass index (62).

- Patients should be encouraged to continue general exercise between supervised outpatient sessions and after completing rehabilitation in order to sustain the beneficial effects of PR (75).

- Patients should improve their quality of sleep by taking regular rest and ensuring sufficient time for sleep (28).

- Survivors of severe COVID-19 and their families should be informed about the features of PICS and its effects on the patient and their family, the long process of recovery, 
the importance of caregiver involvement in treatment and the potential therapeutic strategies that may reduce PICS's impact (46).

- The educational approach must consider the cultural and educational backgrounds of the subjects, and any physical (e.g. hearing or sight impairment) and/or cognitive barriers (75).

\section{Conclusion}

Varying disabilities including pulmonary, neurological, cardiac, musculoskeletal, cognitive and psychological, as well as dysphasia have been observed among patients who survived critical care, related either directly to COVID-19 or ICU treatment. Some of these disabilities have also been reported in patients who recovered from mild or moderate forms of the disease, as well as in those who were asymptomatic. $\mathrm{PR}$ is deemed to be mandatory to prevent or improve these impairments, whether in the short- or long-term course of recovery. A comprehensive assessment is essential in order to first prescribe an individualised rehabilitation treatment and, second, to identify the appropriate care setting for rehabilitation referral.

\section{References}

1. Lu R, Zhao X, Li J, Niu P, Yang B, Wu H, et al. Genomic characterisation and epidemiology of 2019 novel coronavirus: Implications for virus origins and receptor binding. The lancet. 2020;395: 565-574.

2. Guo YR, Cao QD, Hong ZS, Tan YY, Chen SD, Jin HJ, et al. The origin, transmission and clinical therapies on coronavirus disease 2019 (COVID-19) Outbreak - An Update on the Status. Military Medical Research. 2020;7: 11.

3. World Health Organization. Novel coronavirus-China. Available from: https://www.who.int/csr/don/12-january-2020-novel-coronavirus-china/en/. Accessed 11 March 2020.

4. World Health Organization. WHO characterizes COVID-19 as a pandemic - 11 March 2020. Available from: https://www.who.int/ emergencies/diseases/novelcoronavirus-2019/events-as-theyhappen. Accessed 17 March 2020.

5. Lai CC, Shih TP, Ko WC, Tang HJ, Hsueh PR. Severe acute respiratory syndrome coronavirus 2 (SARS-CoV-2) and coronavirus disease-2019 (COVID-19): The epidemic and the challenges. International Journal of Antimicrobial Agents. 2020;55: 105924.

6. World Health Organization. Coronavirus Disease (COVID-19) pandemic. Available from: https://www.who.int/emergencies/diseases/novel-coronavirus-2019. Accessed 17 September 2020.
7. Hamming I, Timens W, Bulthuis ML, Lely AT, Navis GV, van Goor $H$. Tissue distribution of ACE2 protein, the functional receptor for SARS coronavirus. A first step in understanding SARS pathogenesis. The Journal of Pathology. 2004;203: 631-637.

8. Zou X, Chen K, Zou J, Han P, Hao J, Han Z. Single-cell RNAseq data analysis on the receptor ACE2 expression reveals the potential risk of different human organs vulnerable to 2019nCOV infection. Frontiers of Medicine. 2020;14: 185-192.

9. Thomas P, Baldwin C, Bissett B, Boden I, Gosselink R, Granger $\mathrm{CL}$, et al. Physiotherapy management for COVID-19 in the acute hospital setting: Clinical practice recommendations. Journal of Physiotherapy. 2020; 66: 73-82.

10. Zhou M, Zhang X, Qu J. Coronavirus disease 2019 (COVID-19): A clinical update. Frontiers of Medicine. 2020;14: 126-135.

11. Cheema M, Aghazadeh $\mathrm{H}$, Nazarali S, Ting A, Hodges J, McFarlane A, et al. Keratoconjunctivitis as the initial medical presentation of the novel coronavirus disease 2019 (COVID-19). Canadian Journal of Ophthalmology. 2020;55: e125-e129.

12. Vaira LA, Salzano G, Deiana G, De Riu G. Anosmia and ageusia: Common findings in COVID-19 patients. The Laryngoscope. 2020;130: 1787.

13. Adhikari SP, Meng S, Wu YJ, Mao YP, Ye RX, Wang QZ, et al. Epidemiology, causes, clinical manifestation and diagnosis, prevention and control of coronavirus disease (COVID-19) during the early outbreak period: A scoping review. Infectious Diseases of Poverty. 2020;9: 29.

14. Ye $Q$, Wang $B$, Mao J. The pathogenesis and treatment of the Cytokine Storm' in COVID-19. Journal of Infection. 2020;80: 607-613.

15. Yavuz S, Ünal S. Antiviral treatment of COVID-19. Turkish Journal of Medical Sciences. 2020;50: 611-619.

16. Stringer KA, Puskarich MA, Kenes MT, Dickson RP. COVID-19: The uninvited guest in the intensive care unit - Implications for pharmacotherapy. Pharmacotherapy. 2020;40: 382-386.

17. Wujtewicz M, Dylczyk-Sommer A, Aszkiełowicz A, Zdanowski S, Piwowarczyk S, Owczuk R. COVID-19 - What should anaethesiologists and intensivists know about it?. Anaesthesiology Intensive Therapy. 2020;52: 34-41.

18. Chan KS, Zheng JP, Mok YW, Li YM, Liu YN, Chu CM, et al. SARS: Prognosis, outcome and sequelae. Respirology. 2003;8 Suppl: S36-S40.

19. Lee AM, Wong JG, McAlonan GM, Cheung V, Cheung C, Sham $\mathrm{PC}$, et al. Stress and psychological distress among SARS survivors 1 year after the outbreak. The Canadian Journal of Psychiatry. 2007;52: 233-240.

20. Landry MD, Geddes L, Moseman AP, Lefler JP, Raman SR, et al. Early reflection on the global impact of COVID19, and implications for physiotherapy. Physiotherapy. 2020;107: A1-A3.

21. Levy J, Léotard A, Lawrence C, Paquereau J, Bensmail D, Annane $D$, et al. A model for a ventilator-weaning and early rehabilitation unit to deal with post-ICU impairments follow- 
ing severe COVID-19. Annals of Physical and Rehabilitation Medicine. 2020;63: 376-378.

22. Kiekens C, Boldrini P, Andreoli A, Avesani R, Gamna F, Grandi $M$, et al. Rehabilitation and respiratory management in the acute and early post-acute phase. "Instant Paper from the Field" on rehabilitation answers to the COVID-19 emergency. European Journal of Physical and Rehabilitation Medicine. 2020;56: 323-326.

23. Carda $S$, Invernizzi M, Bavikatte $G$, Bensmail $D$, Bianchi $F$, Deltombe $\mathrm{T}$, et al. The role of physical and rehabilitation medicine in the COVID-19 pandemic: The clinician's view. Annals of Physical and Rehabilitation Medicine. 2020;S1877-0657: 3007630082.

24. Stam HJ, Stucki G, Bickenbach J. Covid-19 and post intensive care syndrome: A call for action. Journal of Rehabilitation Medicine. 2020;52: jrm00044.

25. Khan F, Amatya B. Medical rehabilitation in pandemics: Towards a new perspective. Journal of Rehabilitation Medicine. 2020;52: jrm00043.

26. Shang Y, Xu C, Jiang F, Huang R, Li Y, Zhou Y, et al. Clinical characteristics and changes of chest CT features in 307 patients with common COVID-19 pneumonia infected SARS-CoV-2: A multicenter study in Jiangsu, China. International Journal of Infectious Diseases. 2020;96: 157-162.

27. Shi H, Han X, Jiang N, Cao Y, Alwalid O, Gu J, et al. Radiological findings from 81 patients with COVID-19 pneumonia in Wuhan, China: A descriptive study. The Lancet Infectious Diseases. 2020;20: 425-434.

28. Chinese Association of Rehabilitation Medicine; Respiratory Rehabilitation Committee of Chinese Association of Rehabilitation Medicine; Cardiopulmonary Rehabilitation Group of Chinese Society of Physical Medicine and Rehabilitation. [Recommendations for respiratory rehabilitation of coronavirus disease 2019 in adult]. Zhonghua Jie He He Hu Xi Za Zhi. 2020;43: 308-314

29. Liu K, Zhang W, Yang Y, Zhang J, Li Y, Chen Y. Respiratory rehabilitation in elderly patients with COVID-19: A randomized controlled study. Complementary Therapies in Clinical Practice. 2020;39: 101166.

30. Li X, Ma X. Acute respiratory failure in COVID-19: Is it "Typical" ARDS? Critical Care. 2020;24: 198

31. Kakodkar P, Kaka N, Baig MN. A comprehensive literature review on the clinical presentation, and management of the pandemic coronavirus disease 2019 (COVID-19). Cureus. 2020;12: e7560

32. Mo X, Jian W, Su Z, Chen M, Peng H, Peng P, et al. Abnormal pulmonary function in COVID-19 patients at time of hospital discharge. European Respiratory Journal. 2020;55: 2001217.

33. Herridge MS, Tansey CM, Matté A, Tomlinson G, Diaz-Granados N, Cooper A, et al. Functional disability 5 years after acute respiratory distress syndrome. New England Journal of Medicine. 2011;364: 1293-1304.
34. Herridge MS, Cheung AM, Tansey CM, Matte-Martyn A, Diaz-Granados N, Al-Saidi F, et al. One-year outcomes in survivors of the acute respiratory distress syndrome. New England Journal of Medicine. 2003;348: 683-693.

35. Wilcox ME, Herridge MS. Lung function and quality of life in survivors of the acute respiratory distress syndrome (ARDS). La Presse Mediale. 2011;40: e595-e603.

36. Yang LL, Yang T. Pulmonary rehabilitation for patients with coronavirus disease 2019 (COVID-19). Chronic Diseases and Translational Medicine. 2020;6: 79-86.

37. Guan WJ, Ni ZY, Hu Y, Liang WH, Ou CQ, He JX, et al. Clinical characteristics of coronavirus disease 2019 in China. New England Journal of Medicine. 2020;382: 1708-1720.

38. Brodsky MB, Nollet JL, Spronk PE, González-Fernández M. Prevalence, pathophysiology, diagnostic modalities and treatment options for dysphagia in critically ill patients. American Journal of Physical Medicine \& Rehabilitation. 2020;99: 1164-1170. doi: 10.1097/PHM.0000000000001440.

39. Brugliera L, Spina A, Castellazzi P, Climino P, Tettamanti A, Houdayer E, et al. Rehabilitation of COVID-19 patients. Journal of Rehabilitation Medicine. 2020;52: jrm00046.

40. Kochi AN, Tagliari AP, Forleo GB, Fassini GM, Tondo C. Cardiac and arrhythmic complications in patients with COVID-19. Journal of Cardiovascular Electrophysiology. 2020;31: 1003-1008.

41. Barker-Davies RM, O'Sullivan O, Senaratne KP, Baker P, Cranley M, Dharm-Datta S, et al. The Stanford Hall consensus statement for post-COVID-19 rehabilitation. British Journal of Sports Medicine. 2020;54: 949-959.

42. Mao L, Jin $H$, Wang $M, H u Y$, Chen $S, H e ~ Q$, et al. Neurologic manifestations of hospitalized patients with coronavirus disease 2019 in Wuhan, China. JAMA Neurology. 2020;77: 1-9.

43. Padroni M, Mastrangelo V, Asioli GM, Pavolucci L, Abu-Rumeileh $S$, Piscagilia MG, et al. Guillain-Barré syndrome following COVID-19: New infection, old complication?. Journal of Neurology. 2020;267: 1877-1879.

44. Andrenelli E, Negrini F, de Sire A, Arienti C, Patrini M, Negrini S, et al. Systematic rapid living review on rehabilitation needs due to COVID-19: Update to May 31st, 2020. European Journal of Physical and Rehabilitation Medicine. 2020;56: 508-514.

45. Inoue S, Hatakeyama J, Kondo $\mathrm{Y}$, Hifumi T, Sakuramoto $\mathrm{H}$, Kawasaki T, et al. Post-intensive care syndrome: Its pathophysiology, prevention, and future directions. Acute Medicine \& Surgery. 2019;6: 233-246.

46. Smith JM, Lee AC, Zeleznik H, Coffey Scott JP, Fatima A, Needham DM, et al. Home and community-based physical therapist management of adults with post-intensive care syndrome. Physical Therapy. 2020;100: 1062-1073.

47. Piva S, Fagoni N, Latronico N. Intensive care unit-acquired weakness: Unanswered questions and targets for future research. F1000Research. 2019;8: F1000 Faculty Rev-508.

48. Schreiber A, Bertoni M, Goligher EC. Avoiding respiratory and peripheral muscle injury during mechanical ventilation dia- 
phragm-protective ventilation and early mobilization. Critical Care Clinics. 2018;34: 357-381.

49. Li YC, Bai WZ, Hashikawa T. The neuroinvasive potential of SARS-CoV2 may play a role in the respiratory failure of COVID-19 patients. Journal of Medical Virology. 2020;92: 552-555.

50. Rogers JP, Chesney E, Oliver D, Pollak TA, McGuire P, Fusar-Poli $P$, et al. Psychiatric and neuropsychiatric presentations associated with severe coronavirus infections: A systematic review and meta-analysis with comparison to the COVID-19 Pandemic. The Lancet Psychiatry. 2020;7: 611-627.

51. Connolly B, Salisbury L, O'Neill B, Geneen LJ, Douiri A, Grocott MP, et al. Exercise rehabilitation following intensive care unit discharge for recovery from critical illness. Cochrane Database of Systematic Reviews. 2015;2015: CD008632.

52. Tipping CJ, Harrold M, Holland A, Romero L, Nisbet T, Hodgson $\mathrm{CL}$. The effects of active mobilisation and rehabilitation in ICU on mortality and function: A systematic review. Intensive Care Medicine. 2017;43: 171-183.

53. Fuke R, Hifumi T, Kondo Y, Hatakeyama J, Takei T, Yamakawa K, et al. Early rehabilitation to prevent postintensive care syndrome in patients with critical illness: A systematic review and metaanalysis. BMJ Open. 2018;8: e019998.

54. Cuthbertson BH, Rattray J, Campbell MK, Gager M, Roughton $\mathrm{S}$, Smith A, et al. The PRaCTICaL Study of Nurse Led, intensive care follow-up programmes for improving long-term outcomes from critical illness: A pragmatic randomised controlled trial. BMJ. 2009;339: b3723.

55. Godeau E, Debeaumont D, Artaud-Macari E, Lagache L, Bouar GL, Coquart J. Sequelae of acute respiratory distress syndrome: Interest of rehabilitation. Case Reports in Critical Care. 2019;2019: 7953141.

56. Hsieh MJ, Lee WC, Cho HY, Wu MF, Hu HC, Kao KC, et al. Recovery of pulmonary functions, exercise capacity, and quality of life after pulmonary rehabilitation in survivors of ARDS due to severe influenza A (H1N1) pneumonitis. Influenza and Other Respiratory Viruses. 2018;12: 643-648.

57. Jackson J, Ely EW, Morey MC, Anderson VM, Siebert CS, Denne LB, et al. Cognitive and physical rehabilitation of intensive care unit survivors: Results of the RETURN randomized controlled pilot investigation. Critical Care Medicine. 2012;40: 1088-1097.

58. Gordon CS, Waller JW, Cook RM, Cavalera SL, Lim WT, Osadnik CR. Effect of pulmonary rehabilitation on symptoms of anxiety and depression in COPD: A systematic review and meta-analysis. Chest. 2019;156: 80-91.

59. Panagioti M, Scott $C$, Blakemore A, Coventry PA. Overview of the prevalence, impact, and management of depression and anxiety in chronic obstructive pulmonary disease. International Journal of Chronic Obstructive Pulmonary Disease. 2014;9: 1289-1306.

60. British Thoracic Society Standards of Care Subcommittee on Pulmonary Rehabilitation. Pulmonary Rehabilitation. Thorax. 2001;56: 827-834.
61. Rochester CL. Patient assessment and selection for pulmonary rehabilitation. Respirology. 2019;24: 844-853.

62. Simpson R, Robinson L. Rehabilitation after critical illness in people with COVID-19 infection. American Journal of Physical Medicine \& Rehabilitation. 2020;99: 470-474.

63. Spruit MA, Singh SJ, Garvey C, ZuWallack R, Nici L, Rochester $\mathrm{C}$, et al. An official American thoracic society/European respiratory society statement: Key concepts and advances in pulmonary rehabilitation. American Journal of Respiratory and Critical Care Medicine. 2013;188: e13-e64.

64. Aitken LM, Marshall AP. Monitoring and optimising outcomes of survivors of critical illness. Intensive and Critical Care Nursing. 2015;31: 1-9.

65. Major ME, Kwakman R, Kho ME, Connolly B, McWilliams D, Denehy $L$, et al. Surviving critical illness: What is next? An expert consensus statement on physical rehabilitation after hospital discharge. Critical Care. 2016;20: 354.

66. Sheehy LM. Considerations for post-acute rehabilitation for survivors of COVID-19. JMIR Public Health Surveillance. 2020;6: e19462.

67. Wang B, Li R, Lu Z, Huang Y. Does comorbidity increase the risk of patients with COVID-19: Evidence from meta-analysis. Aging (Albany NY). 2020;12: 6049-6057.

68. Hornikx M, Van Remoortel H, Demeyer H, Marcal Camillo CA, Decramer $M$, Janssens $W$, et al. The influence of comorbidities on outcomes of pulmonary rehabilitation programs in patients with COPD: A systematic review. BioMed Research International. 2013;2013: 146148.

69. Vitacca M, Carone M, Clini EM, Paneroni M, Lazzeri M, Lanza A, et al. Joint statement on the role of respiratory rehabilitation in the COVID-19 crisis: The Italian position paper. Respiration. 2020;99: 493-499.

70. Arcuri JF, Abarshi E, Preston NJ, Brine J, Di Lorenzo VA. Benefits of interventions for respiratory secretion management in adult palliative care patients - A systematic review. BMC Palliative Care. 2016;15: 74.

71. Gauld LM. Airway clearance in neuromuscular weakness. Developmental Medicine \& Child Neurology. 2009;51: 350-355.

72. Volsko TA. Airway clearance therapy: Finding the evidence. Respiratory Care. 2013;58: 1669-1678.

73. Stephens RJ, Haas M, Moore III WL, Emmil JR, Sipress JA, Williams A. Effects of diaphragmatic breathing patterns on balance: A preliminary clinical trial. Journal of Manipulative Physiological Therapeutics. 2017;40: 169-175.

74. Pan F, Ye T, Sun P, Gui S, Liang B, Li L, Zheng D, et al. Time course of lung changes at chest $\mathrm{CT}$ during recovery from coronavirus disease 2019 (COVID-19). Radiology. 2020;295: 715-721.

75. Bolton CE, Bevan-Smith EF, Blakey JD, Crowe P, Elkin SL, Garrod R, et al. British Thoracic Society guideline on pulmonary rehabilitation in adults. Thorax. 2013;68 Suppl 2: ii1-ii30. 
76. Macht M, White SD, Moss M. Swallowing dysfunction after critical illness. Chest. 2014;146: 1681-1689.

77. Allingstrup MJ, Kondrup J, Wiis J, Claudius C, Pedersen UG, Hein-Rasmussen R, et al. Early goal-directed nutrition versus standard of care in adult intensive care patients: The single-centre, randomised, outcome assessor-blinded EAT-ICU trial. Intensive Care Medicine. 2017;43: 1637-1647.

78. Lambell KJ, King SJ, Forsyth AK, Tierney AC. Association of energy and protein delivery on skeletal muscle mass changes in critically ill adults: A systematic review. JPEN Journal of Parenteral and Enteral Nutrition. 2018;42: 1112-1122.

79. Rengel KF, Hayhurst CJ, Pandharipande PP, Hughes CG. Longterm cognitive and functional impairments after critical illness. Anesthesia \& Analgesia. 2019;128: 772-780.

80. Cicerone KD, Dahlberg C, Malec JF, Langenbahn DM, Felicetti T, Kneipp S, et al. Evidence-based cognitive rehabilitation: Updated review of the literature from 1998 through 2002. Archives of Physical Medicine and Rehabilitation. 2005;86: 1681-1692. 